\title{
Rehabilitation Program After Surgical Transfer of The Ulnar Nerve to Make Anatomically Adjustment of Its route to Restore The Functional Efficiency of The Injured Hand
}

Dr/ Ahmed Abul Abbas Abdel Hamid*

Introduction and Research Problem:

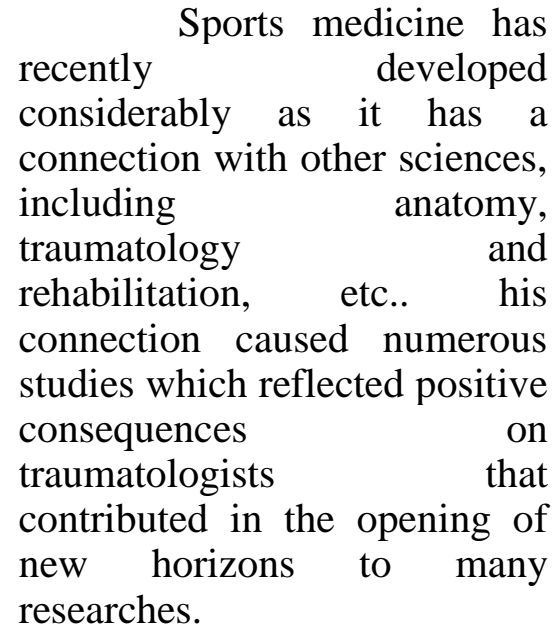

Hassan Mohammed

Nawasrah (2012) indicates that the elbow joint is a single-axis joint, consisting of articulation of the inferior limb of the humerus with the pectoral limb of the radius and ulna. The elbow joint contains a fibrous capsule, and a synovial joint, The injuries of this joint are limited to traumatic bruises, muscle and ligaments rupture, sprain and fracture of one of its constituent bones. These injuries are caused by violent force either directly such as falling on the joint itself or indirectly such as falling on the extended hand with winding and rotation of the forearm. In the case of direct injuries, bruises and fractures of the joint often occur. In indirect cases, sprain, rupture in ligaments or dislocation of the joint, usually deformation depending on the mechanism of injury in terms of bone shift. (11: 211)

As Muhammad Qadri Bakri, Siham al-Ghamri (2005), explains that the elbow joint dislocation or fracture, change the place of the bones that form the joint from its natural alignment by a strong action, usually when the fall is mitigated by an open hand. The elbow joint is the second most common joint which exposes to dislocation after the shoulder in adults, and elbow joint dislocation may make consequences if the dislocated elbow forms pressure or blocks blood vessels and nerves that

*Lecturer of Anatomy, Department of Sports Health Sciences - Mansoura University 
fed the arm and hand. (26: 110-11) Mohammed Fathy Hendi (1991) and Iqbal Rasmi Mohammed (2008) indicate that the anatomical properties of the ulnar nerve extend near the ulna bones, and it is the largest nerve in the human body without protection (not protected by muscles or bones) so the injury is more likely as the nerve gives sensory neural nutrition to the medial side of the back of the hand (the exterior of the pinky and the exterior of the medial half of the manus) and arises from the medial cord of the brachial plexus of the eighth cervical nerve and first dorsal nerve as its fibers come from the seventh cervical nerve and head down through the armpit between the axillary artery and vein and take a special route up to the elbow joint to Pass in the gutter of the medial ganglion of the humerus, Where it can be induced under the skin and press on it, thus the person feels an electric shudder in his pinky and the manus fingers. Joint of the elbow reaches up to the forearm between the two heads of the musculus flexor carpi ulnaris behind and continue until it is divided into two branches: the surface branch and the final cavernous branch. (25: 260) (7: 168)
Farraj Abdel Hamid Tawfik (2005) indicates that the nerves act as the mastermind and commander of the human body, and the peripheral nerves represent the function of the mediator who receives the orders of the brain and works to implement it accurately. The nerves cover all parts of the body as there is not one millimeter in the human body which is not covered with nerves Therefore, if any nerve is injured, the part that is fed by this nerve cannot work on its own, so it loses its function and as a result it cannot be used and started in its way to atrophy. (18: 263).

The nerve consists of nerve fibers, which are extensions of nerve cells. These extensions carry some sensory stimuli to the central nervous system, some carry kinetic stimulators from the central nervous system and some carry kinetic stimulators from the central nervous system to the muscles. The nervous extension is surrounded by a fatty insulating material called "Melanin"and then the nerve membrane. (82:2)

Injury and paralysis of the nerve result from severe injury or from excessive repetitive stresses, which lead 
to inflammation and swelling of the nerve. It may also be the result of anatomical structure (Muscles, vessels, ligaments), or pathological factors such as aneurysms, inflammation). Excessive pressure on the nerve and stress due to swelling, fracture or dislocation of the elbow and ulnar nerve damage is like cutting the connecting cord of brain messages that cannot be transmitted to your finger (4: 1$)$ Magdi Mahmoud and Cook (1996) indicate that physical rehabilitation is the restoration of both the normal function and shape of the organ after injury, where the sports rehabilitation of the athlete is the rehabilitation of the injured athlete at the highest functional level in the least time possible. (21:28)

Kramer et al. (2003) also note that kinetic therapy is particularly important after surgical intervention as the success of surgery in this case is an important part of treatment, and physical rehabilitation is responsible of another more important part as the return of the injured part to the performance of its functions and efficiency is greatly affected by the degree and level of physical rehabilitation. (43: 274)
Stalkers, B (2008) notes that a physical rehabilitation specialist who is responsible of the implementation of the program must take into account several considerations, including understanding the synthesis and the physiology function of the joint, the endogenous receptors associated with it and its kinetic system, as an attempt to restore and improve the player's ability to perform physically while avoiding being injured again by performing exercises (51: 106). Alvinn j. Determine (2008) mentions that the rehabilitation exercises are divided into negative exercises, which is the first stage of rehabilitation for the purpose of activating the injured organ and accompanied by the use of physical therapy, passive training, where the therapist helps the injured in moving the injured part, assistive training which are performed in the direction of gravity, and resistive training performed by the injured for the purpose of strength using resistors (35: 153).

$$
\text { Laila El Sayed Farhat }
$$

(2001), Farid Mahmoud Othman (2000), and Owais Ali Al-Jabali (2000) agree that the flexibility of the joint means the performance of the 
movement in the widest possible range. The flexibility especially helps to save energy of the joint, reducing performance time, showing movements in a more fluid form, and helping to recover quickly after injury, and reducing the sensation of muscle pain. The importance of flexibility is shown to be a key factor in the development of both muscle strength and speed as it is considered one of the most important factors to protect the joint from injury. (20: 152) (19: 447) (16: 125).

The researcher sees through observation of a number of ulnar nerve patients in physiotherapy centers and he began to collect information about that problem by using references, studies and researches. When the problem settled in the conscience of the researcher through his sense of what the researcher began to work on the study of this problem. Ulnar neuropathy can appear in various ways (excessive pressure on the nerve - stress due to swelling fracture or dislocation of the elbow), which leads to loss of sensitivity in the entire little finger, or half of it, as well as the normal performance of flexor muscles and adductor pollicis muscles.
Muscle cells develop paralysis, which is responsible for flexion of the fingers. This is mainly observed in the place where the nervi digitales pass, as the simultaneous curvature of the fingers occurs in the joints. I $\mathrm{f}$ the problem is minor, the weakness develops, the muscle size decreases significantly, and thus affects the area between the thumb, forefinger and other areas between the fingers. Paralysis may lead to feeling of tingling and burning in the inside of the palm of the hand,then the little finger and the adjacent area start to point to the circular finger gradually, then these areas lose feeling completely, and the pain develops, if not treated in appropriate time. It may develop into muscle atrophy, gradual loss of sensation, especially in the fingers, and the damage gradually extends to the neighboring nerve area, on the course of the entire length of the nerve.

These symptoms are associated with a decrease in strength of the muscle and may lead to complete paralysis, numbness and topoalgia may appear in the point of injury, and then can spread throughout the entire nerve. Hence the idea of the researcher was to design a therapeutic rehabilitation 
program after the surgical transfer of the ulnar nerve after making anatomically adjustment of its route to restore the functional efficiency of the injured hand, as well as improving the kinetic range in grapping and extension of the wrist and elbow joints leading to the disappearance of pain. This rehabilitation program is subjected subject to the attempt to determine the impact on the functional efficiency of the joint and the extent of its ability to meet the kinetic requirements of the individual with ulnar nerve.

\section{Importance of the Research:}

The research process has three main aspects:

\section{1- Scientific Importance:}

This research is one of the scientific attempts to study the functional anatomical foundations for the design of the a therapeutic rehabilitation program after the surgical transfer of the ulnar nerve after making anatomically adjustment of its route to restore the functional efficiency of the injured hand, which helps the injury to not aggravate and return of the injured individual to normal case.

\section{2- Applied Importance:}

The results of this research can help the workers in therapeutic rehabilitation field to deepen the methods of rehabilitation and increase the applications of anatomical foundations whether in examination, follow-up or rehabilitation, which increases the effectiveness of the therapeutic rehabilitation program. Through the study of scientific studies and research that took place in the Egyptian environment and, within the limits of the researcher's knowledge, it was noted that few studies dealt with the anatomical measurements of ulnar nerve injury, so the researcher hopes that this study will be a new scientific addition to avoid ulnar nerve injury and to help in constructing therapeutic rehabilitation programs.

\section{Research Objectives:}

A therapeutic rehabilitation program after the surgical transfer of the ulnar nerve after making anatomically adjustment of its route to restore the functional efficiency of the injured hand, by identifying:

1- Anatomical evaluation of the kinetic and sensory ulnar nerve in the research sample.

2- Analysis of the electrical activity of the muscles of the forearm and hand wrist in the research sample.

3- Strength of the grip and kinetic range of hand wrist joint in the research sample. 
4- The degree of pain associated to the injury in the research sample.

\section{Research hypotheses:}

1- There are statistically significant differences between the averages of the pre- and post-measurements of the experimental group in favor of the post-measurements in the improvement of the anatomical evaluation of the kinetic and sensory ulnar nerve in the research sample.

2- There are statistically significant differences between the averages of the pre- and post-measurements of the experimental group in favor of the post measurements in the improvement of electrical activity of the forearm muscles and hand wrist in the research sample.

3- There are statistically significant differences between the averages of the pre- and post-measurements of the experimental group in favor of the post measurements in the improvement of the grip strength and kinetic range of the wrist joint in the research sample.

4- There are statistically significant differences between the averages of the pre- and post-measurements of the experimental group in favor of the post measurements in the improvement of degree of pain associated to the injury in the research sample.

\section{Research Terms:}

\section{Functional Anatomy}

Hassan Mohammed

Nawasra (2012) indicates that it is a science that interested in the knowledge of the organs of the human body and their relationship to each other such as the skeletal and articular, muscular and nervous system. (11:14)

\section{Ulnar nerve}

It is the largest nerve in the human body, extends near the ulna bones and it is not protected by bone muscles, so the injury is more likely. It gives sensory neural nutrition to the medial side of the back of the hand (the exterior of the pinky and the exterior of the medial half of the manus) and can be examined functionally by dispersing and assembling fingers). (97:50)

\section{Rehabilitation program:}

Mohammed Mustafa Fadl (2007) indicates it as the treatment and training of the injured to recover the functional capacity in the shortest possible time by using the means that suit the type and intensity of injury. (27: 8)

Rehabilitation exercise: Iqbal Rasmi Mohammed (2008) indicates it 
as to a group of exercises intended to asses or treat an injury or deviation of the normal state that leads to the loss or hindrance of the full function of the member in, order to help this member to return to normal. (7:40)

Related Studies in Arabic and English:

1- Ahmed Salah Qaraah (2001) (3): A study under a heading "a proposed rehabilitation program to restore the efficiency of some joints affected by burns" The study aimed at designing a proposed rehabilitation program to get rid of some contractions and stiffening of joints. The research sample consisted of (49) individuals who suffer from burns in both the elbow joint and wrist, (5) individuals who are patients with stiff bone were excluded and thus the research sample reached (44) individuals and their ages between (52:50) years. One of the most important results of was the high efficiency of the joints and improvement of the functional performance and muscle work for burns by using the proposed rehabilitation program for different age stages provided that the earliness when the patient submits.

1 -

Mohamed

Abdel
Aziz Mohamed (2002) (24) A study entitled "The confirmation of therapeutic exercises on some physical and physiological variables associated with arthralgic inflammation of the hand wrist joint". The study aimed to identify the effect of therapeutic exercises on some physical and physiological variables associated with arthralgic inflammation of the hand wrist. The researcher used the experimental method by choosing the method of pre and post measurement with a sample of (30) women. The results were that the proposed program had a positive effect on improving and increasing kinetic range, muscle strength and reducing pain level.

2- Ehab Ahmed Mansour (2005) (9) A study entitled" Rehabilitation program for the muscles working on the arm after carpal tunnel release of the middle nerve of the hand. The research aimed to construct a rehabilitation program for the muscles working on the arm after carpal tunnel release of the middle nerve of the hand to identify the effect of the program on some physical and physiological variables The researcher used the experimental method in a 
multiple measurements method. The research sample consisted of (10) individuals who had the carpal tunnel release process and the results were positive in improving the rate of carriage of nerve fibers to the middle nerve as there was an improvement in the strength of the muscles working on the arm.

3- Ahmed Helmy Ibrahim (2009) (1): A study entitled "Rehabilitation program and the impact on carpal tunnel syndrome without surgery". The study aimed to identify the impact of a rehabilitation program on patients with carpal tunnel syndrome without surgery in the variables of the nervous conduction, kinetic range and grip strength. The researcher used the experimental method on a sample of (10) men and women with an average age (28) years and the results showed a presence of statistically significant differences in favor of the rehabilitation program in the post -measurement as there was an improvement in variables under research.

3- Thabet Rabie Thabet (2012) (10): A study entitled "The effect of a proposed rehabilitation program using exercise and ultrasound on some athletes with
Epicondylitis at the elbow joint. The study aimed to identify the effect of a proposed rehabilitation program using exercise and ultrasound on some athletes with Epicondylitis at the elbow joint. The researcher used the experimental method on the sample of (12) athletes with an average age of (30:18) years. The results showed a presence of statistically significant differences in favor of the rehabilitation program in the post -measurement as there was an improvement in variables under research.

5- Study of Brighton Loeb and Fareed Miro (2001) (36): A study entitled "The effect of a long-term program on the hand infected with rheumatoid arthritis". The study aimed to know the impact of exercise on the muscle strength that surrounds the joints affected in a group of patients. The study sample (44) women were divided into two groups: experimental consisted of (20) women and another control consisted of (22) patients. The researcher used the experimental method in the control group, in the muscle strength of the muscle group that control the affected joints. 5- Nathan Ba et al. (2001) (46) A study entitled "The effect of 
aerobic exercise in the conduction of the middle nerve and the symptoms associated with carpal tunnel syndrome". The study aimed to determine the impact of aerobic exercise on the conduction of the middle nerve and symptoms associated with carpal tunnel syndrome. The researcher used the experimental method in a sample of (30) volunteers from (30 - 64) years. The results showed the importance of aerobic exercise program in improving the functions of the middle nerve with reducing the limit of symptoms in hand.

6- Boonhong $\mathrm{J}$ piravej $\mathrm{K} \mathrm{C}$. (2004) (38) A study entitled "The effect of therapeutic sound waves in simple and modified carpal tunnel syndromes". The study aimed to clarify the effect of the low severity of ultrasound waves in the treatment of simple and modified carpal tunnel syndrome. The researcher used the experimental method in a sample of (18) women suffering from carpal tunnel syndrome (CTS). The results showed that the effect of the low severity of ultrasound waves was great in the case of simple and modified carpal tunnel syndromes.

7- Pinar L et al. (2005) (49) A study entitled "Can we use nerve displacement exercises in symptoms of carpal tunnel syndrome in women". The study aimed to determine the effect of the use of nerve displacement exercises mixed with theories of conservative treatments in patients with carpal tunnel syndrome. The researcher used the experimental method in a sample of (26) patient. The results showed a rapid improvement in reducing pain with the emergence of significant functional improvement, especially in the strength of grapping.

8- Neves et al (2005) (47) a study entitled "The preventive and therapeutic effect of physical activity in carpal tunnel syndrome". The study aimed to include the completion of the references concerned with carpal tunnel syndrome and to verify the data that allows to clarify the preventive role of physical activity. The researcher used the survey method. The most important results of the research was to clarify that the preventive effect of physical activity on carpal tunnel syndrome was very few and contain mostly insufficient number in the sample. However, according to the study, the importance of 
conducting further experimental studies on the potential impact of the physical activity on carpal tunnel syndrome.

9- Stirgiolas (2007) (52): A study entitled "The effect of laser with a low level of exercise in the treatment of removal of the lateral membrane of the elbow joint". The study aimed to compare the effectiveness of the laser with the exercise program and the effectiveness of the placebo laser with the same exercise program in the treatment of removal of the lateral membrane of the elbow joint. The researcher used the experimental method and selected a sample of (50) patients who were randomly selected and divided into two groups (a) (25) and were submitted to laser treatment with chemical weapons and exercise program. Group B (25) was subjected to placebo laser therapy in addition to the same exercise program. The center of the injury site and reduce pain when choosing a grip strength and increase the range of wrist joint and increase the grip strength. The results showed that laser therapy with exercise program was more effective than placebo laser therapy with the same exercise program in both pain relief when touching, pain relief when pressing the middle finger on the site of the injury, and pain relief when choosing a grip strength measurement, increasing the kinetic range of wrist joint and increasing the grip strength.

10- Brininger TL et al. (2007) (37): A study entitled "Efficacy of a designed splint with nerve displacement exercises for the treatment of carpal tunnel syndrome". The aim of this study was to compare the wrist condition in neutral wrist splint (lower joints and wrist with stent splint) with or without exercise to treat carpal tunnel syndrome. The researcher used the experimental method in a sample of (61) individuals, 51 of them completed. The results showed the preference of the neutral wrist splint in fixation of wrist and knuckles rather than the cock- up splint.

11- Su x, wu zq, cao xm (2010) (53): A Study entitled "Electrical stimulation by different frequencies to treatment patients with tennis elbow". The study aimed to take into account the different effects of different electrical frequencies. The researcher used the experimental method and selected a sample of (85) and they were divided into two 
groups (41) who were subjected to a continuous electrical wave, and a group of (44) who were subjected to the disruption of the electrical wave, the optical symmetry was used to reduce the intensity of pain. The results showed that the group of (41) who were subjected to a continuous electrical wave has a cure rate of $7.31 \%$, while of (44) who were subjected to the disruption of the electrical wave has a cure rate of $8.56 \%$. In summary, Electrical wave disturbance treatment is better than continuous electrical wave therapy.

12- Ekim A (2007) (41): A study entitled "The effect of reduced dose of therapeutic laser in rheumatoid patients with carpal tunnel syndrome". The study aimed to evaluate the effectiveness of the low level of therapeutic laser in rheumatoid arthritis patients with carpal tunnel syndrome. The researcher used the experimental method in a sample included (19) patients. The results showed the effect of low level of therapeutic laser plasio in improving the degree of pain and hand functions for people with carpal tunnel syndrome.

13- Clarke, Ahmad, Curtis and Connell da (2010) (40): A
Study entitled "The effect of ultrasound on pain and functional deficits on the lateral ligament of the elbow joint (lateral elbow)". The study aimed to prove the effect of ultrasound on pain and functional deficits on the lateral ligament of the elbow joint. The researcher used the experimental method on the sample of (62) (30 males - 32 females) and all subjected to ultrasound. After 6 months of standardized treatment, the results revealed that there is a positive correlation between ultrasound and its effect on the severity of pain in the lateral ligament of the elbow joint. There was any relationship with age or sex. Ultrasound therapy,by its effect on the severity of pain in the lateral ligament of the elbow joint, led to assess the severity and strength of the lateral ligament. The response to treatment was low in pain intensity and functional deficits and this may be an indicator of poor diagnosis.

The extent of benefit from previous associated studies:

Through the
classification, study and
analysis of these studies and
previous research, The
researcher was be able
determine the benefit of:


1- Determining the procedures and steps followed in conducting the research.

2- Determining the anatomical, morphological and physical variables of the research sample.

3- Determining the appropriate instruments, tools and tests to measure research variables.

4- Select the appropriate method for the nature of the research.

5- How to use laws and statistical treatments which are appropriate to the nature of the research.

\section{Research procedures:}

Research Methodology:

The researcher used the experimental method as it suits the nature and purpose of the research by using the pre and post experimental design with one experimental group system.

\section{The Research Sample:}

The research community was deliberately selected from the ulnar nerve patients, the number of (4) individuals infected with ulnar nerve from the age $(30-45)$ years, after the consent of the injured as well as the approval of the doctors and all health authorities to implement the rehabilitation program after full review and allow the completion of measurements of the sample accurately and health care and after adjusting the research variables for one experimental group

\section{Sample selection conditions:}

The nature of this research requires that the sample members meet the following conditions:

1- Agree to conduct the research experiment.

2- Attend a proposed rehabilitation program throughout the duration of the experiment.

3- No injury to the individual affecting the implementation of the proposed rehabilitation units in the program.

4- The sample should not be subjected to any other program during the research sample experiment.

5- Volunteer in conducting the experiment and regularity in the rehabilitation units of the program throughout the study period.

6- The research sample to be diagnosed by a doctor who specializes in ultrasound (radiologist).

Characteristics of the research sample:

The researcher

collected data about the individuals in the variables of age, height, weight and some morphological and anatomical measurements of the nerve and 
muscles as well as measurements of the degree of pain, grip strength and kinetic range of the wrist joint, which is the joint affected by the injury of the sample before starting the rehabilitation

\section{Table (1)}

program.

\section{Homogeneity of the research sample:}

Homogeneity of the search sample was performed in the key variables being searched.

\section{Homogeneity of the search sample in the basic variables being searched $N=4$}

\begin{tabular}{|c|c|c|c|c|c|}
\hline Variables & $\begin{array}{c}\text { Measuring } \\
\text { Unit }\end{array}$ & SMA & Mediator & $\begin{array}{l}\text { Standard } \\
\text { Deviation }\end{array}$ & $\begin{array}{l}\text { Torsiona } \\
\text { modulus }\end{array}$ \\
\hline Age & Year & 34.600 & 32.000 & 6.107 & 1.762 \\
\hline weight & $\mathrm{Cm}$ & 81.200 & 81.000 & 1.923 & .590 \\
\hline Length & $\mathrm{Cm}$ & 174.600 & 174.000 & 1.517 & 1.118 \\
\hline Upper arm length & $\mathrm{Cm}$ & 31.800 & 32.000 & 0.837 & 0.512 \\
\hline Forearm length & $\mathrm{Cm}$ & 24.200 & 24.000 & 0.837 & -0.512 \\
\hline Arm length & $\mathrm{Cm}$ & 73.400 & 74.000 & 0.894 & -1.258 \\
\hline $\begin{array}{c}\text { Extended Upper } \\
\text { armcircumference }\end{array}$ & $\mathrm{Cm}$ & 26.600 & 27.000 & 1.140 & -0.405 \\
\hline $\begin{array}{l}\text { Constritced } \\
\text { Upper arm circumference }\end{array}$ & $\mathrm{Cm}$ & 34.400 & 35.000 & 0.894 & -1.258 \\
\hline $\begin{array}{c}\text { forearm } \\
\text { circumference }\end{array}$ & $\mathrm{Cm}$ & 22.800 & 23.000 & 0.837 & 0.512 \\
\hline $\begin{array}{l}\text { Hand wrist } \\
\text { circumference }\end{array}$ & $\mathrm{Cm}$ & 15.400 & 15.000 & 0.548 & 0.609 \\
\hline
\end{tabular}

It is clear from Table (1) that the basic variables under consideration are all homogeneous, which indicates the homogeneity of the study
Table (2)

group in these measurements, and Torsional modulus is between $(+3,-3)$ and this gives a direct indication of homogeneity.

Homogeneity of the research sample in the variables of anatomical evaluation of kinetic and sensory conduction of the ulnar nerve under consideration $N=4$

\begin{tabular}{|c|c|c|c|c|c|c|}
\hline Variables & & $\begin{array}{c}\text { Measuring } \\
\text { Unit }\end{array}$ & $\overline{~ S M A ~}$ & Mediator & $\begin{array}{l}\text { Standard } \\
\text { Deviation }\end{array}$ & $\begin{array}{c}\text { Torsional } \\
\text { modulus }\end{array}$ \\
\hline \multirow{2}{*}{$\begin{array}{c}\text { Anatomical } \\
\text { evaluation } \\
\text { of kinetic } \\
\text { conduction } \\
\text { of the ulnar } \\
\text { nerve }\end{array}$} & $\begin{array}{l}\text { Time taken } \\
\text { for neuronal } \\
\text { conduction }\end{array}$ & MS & 5.060 & 5.100 & 0.207 & -0.236 \\
\hline & $\begin{array}{c}\text { Nerve } \\
\text { conduction } \\
\text { force }\end{array}$ & MV & 8.480 & 8.400 & 0.164 & 0.518 \\
\hline
\end{tabular}




\section{Follow Table (2)}

Homogeneity of the research sample in the variables of anatomical evaluation of kinetic and sensory conduction of the ulnar nerve under consideration $N=4$

\begin{tabular}{|c|c|c|c|c|c|c|}
\hline Variables & & $\begin{array}{c}\text { Measuring } \\
\text { Unit }\end{array}$ & SMA & Mediator & $\begin{array}{l}\text { Standard } \\
\text { Deviation }\end{array}$ & $\begin{array}{l}\begin{array}{l}\text { Torsional } \\
\text { modulus }\end{array} \\
\text { modis }\end{array}$ \\
\hline & $\begin{array}{c}\text { Conduction } \\
\text { speed }\end{array}$ & MS & 50.200 & 50.000 & 0.837 & 0.512 \\
\hline & $\begin{array}{c}\text { Conduction } \\
\text { time }\end{array}$ & MS & 34.820 & 34.900 & 0.750 & -1.272 \\
\hline \multirow{3}{*}{$\begin{array}{l}\text { Anatomical } \\
\text { evaluation } \\
\text { of sensory } \\
\text { conduction } \\
\text { of the ulnar } \\
\text { nerve }\end{array}$} & $\begin{array}{l}\text { Time taken } \\
\text { for neuronal } \\
\text { conduction }\end{array}$ & MS & 3.320 & 3.300 & 0.130 & 0.541 \\
\hline & $\begin{array}{c}\text { Nerve } \\
\text { conduction } \\
\text { force }\end{array}$ & MV & 11.200 & 11.000 & 0.837 & 0.512 \\
\hline & $\begin{array}{c}\text { Conduction } \\
\text { time }\end{array}$ & MS & 3.740 & 3.800 & 0.089 & -1.258 \\
\hline $\begin{array}{l}\text { It } \\
\text { (2) that } \\
\text { under cc } \\
\text { homogen } \\
\text { the homo }\end{array}$ & $\begin{array}{l}\text { s clear fr } \\
\text { he basic } \\
\text { ssideration } \\
\text { tus, which } \\
\text { eneity of }\end{array}$ & $\begin{array}{l}\text { Table } \\
\text { variables } \\
\text { are all } \\
\text { indicates } \\
\text { he study }\end{array}$ & \multicolumn{4}{|c|}{$\begin{array}{l}\text { group in these measurements, } \\
\text { and Torsional modulus is } \\
\text { between }(+3,-3) \text { and this gives } \\
\text { a direct indication of }\end{array}$} \\
\hline
\end{tabular}

\section{Table (3)}

Homogeneity of the research sample in the variables of analysis of the electrical activity of forearm muscles and The wrist of the hand under consideration $N=4$

\begin{tabular}{|c|c|c|c|c|c|c|}
\hline \multicolumn{2}{|c|}{ Variables } & $\begin{array}{c}\text { Measuring } \\
\text { Unit }\end{array}$ & SMA & Mediator & Standard & Torsional \\
\hline \multirow{3}{*}{$\begin{array}{l}\text { Flexor carpi } \\
\text { ulnaris }\end{array}$} & $\begin{array}{l}\begin{array}{l}\text { Systolic force } \\
\text { of the muscle }\end{array}\end{array}$ & MV & 2.420 & 2.400 & 0.084 & -0.512 \\
\hline & $\begin{array}{c}\text { Systole } \\
\text { duration }\end{array}$ & MS & 25.160 & 25.200 & 0.385 & 0.332 \\
\hline & $\begin{array}{c}\text { Number of } \\
\text { systole stages }\end{array}$ & stage & 7.600 & 8.000 & 0.548 & -0.609 \\
\hline \multirow{3}{*}{$\begin{array}{l}\text { Musculus flexor } \\
\text { digitorum } \\
\text { profundus }\end{array}$} & $\begin{array}{l}\text { Systolic force } \\
\text { of the muscle }\end{array}$ & $\mathrm{MV}$ & 4.360 & 4.300 & 0.182 & 0.567 \\
\hline & $\begin{array}{c}\text { Systole } \\
\text { duration }\end{array}$ & MS & 30.320 & 30.300 & 0.130 & 0.541 \\
\hline & $\begin{array}{c}\text { Number of } \\
\text { systole stages }\end{array}$ & stage & 11.400 & 11.000 & 0.548 & 0.609 \\
\hline \multirow{3}{*}{$\begin{array}{c}\text { Musculus } \\
\text { abductor digiti } \\
\text { quinti manus }\end{array}$} & $\begin{array}{l}\text { Systolic force } \\
\text { of the muscle }\end{array}$ & $\mathrm{MV}$ & 2.320 & 2.300 & 0.084 & -0.512 \\
\hline & $\begin{array}{c}\text { Systole } \\
\text { duration }\end{array}$ & MS & 28.520 & 28.700 & 0.492 & -0.620 \\
\hline & $\begin{array}{c}\text { Number of } \\
\text { systole stages }\end{array}$ & stage & 11.400 & 11.000 & 0.548 & 0.609 \\
\hline
\end{tabular}


Follow Table (3)

Homogeneity of the research sample in the variables of analysis of the electrical activity of forearm muscles and The wrist of the hand under consideration $N=4$

\begin{tabular}{c|c|c|c|c|c|c}
\hline \multicolumn{2}{c|}{ Variables } & $\begin{array}{c}\text { Measuring } \\
\text { Unit }\end{array}$ & SMA & Mediator & $\begin{array}{c}\text { Standard } \\
\text { Deviation }\end{array}$ & $\begin{array}{c}\text { Torsional } \\
\text { modulus }\end{array}$ \\
\hline \hline \multirow{2}{*}{$\begin{array}{c}\text { Musculus } \\
\text { interosseus } \\
\text { dorsalis }\end{array}$} & $\begin{array}{c}\text { Systolic } \\
\text { force of the } \\
\text { muscle }\end{array}$ & MV & 1.880 & 1.900 & 0.084 & 0.512 \\
\cline { 2 - 7 } & $\begin{array}{c}\text { Systole } \\
\text { duration }\end{array}$ & MS & 27.360 & 27.400 & 0.619 & -0.819 \\
\cline { 2 - 7 } & $\begin{array}{c}\text { Number of } \\
\text { systole stages }\end{array}$ & Stage & 8.200 & 8.000 & 0.837 & -0.512 \\
\hline \multirow{2}{*}{$\begin{array}{c}\text { Musculus flexor } \\
\text { digitorum } \\
\text { profthe force } \\
\text { profundus(Forth }\end{array}$} & $\begin{array}{c}\text { Systole } \\
\text { duration }\end{array}$ & MV & 2.540 & 2.600 & 0.134 & -0.166 \\
\cline { 2 - 7 } & $\begin{array}{c}\text { Number of } \\
\text { systole stages }\end{array}$ & Stage & 10.200 & 10.000 & 0.837 & -0.512 \\
\hline \hline
\end{tabular}

\section{It is clear from Table}

(3) that the basic variables under consideration are all homogeneous, which indicates the homogeneity of the study

\section{Table (4)}

group in these measurements, and Torsional modulus is between $(+3,-3)$ and this gives a direct indication of homogeneity.

Homogeneity of the research sample in the physical variables under consideration $N=4$

\begin{tabular}{c|c|c|c|c|c}
\hline \hline Variables & $\begin{array}{c}\text { Measuring } \\
\text { Unit }\end{array}$ & SMA & Mediator & $\begin{array}{c}\text { Standard } \\
\text { Deviation }\end{array}$ & $\begin{array}{c}\text { Torsional } \\
\text { modulus }\end{array}$ \\
\hline \hline Grip Strength & KG & 15.400 & 15.000 & 1.140 & 0.405 \\
\hline \multirow{3}{*}{$\begin{array}{c}\text { Kinetic range } \\
\text { of hand wrist }\end{array}$} & Systole & 122.626 & 122.450 & 0.396 & 0.487 \\
\cline { 2 - 6 } & extension & 77.242 & 77.300 & 0.295 & -0.874 \\
\cline { 2 - 6 } & allurement & 37.340 & 37.300 & 0.434 & 0.651 \\
\cline { 2 - 6 } & retraction & 23.848 & 23.800 & 0.163 & 0.954 \\
\hline \hline
\end{tabular}

It is clear from Table

(4) that the basic variables under consideration are all homogeneous, which indicates the homogeneity of the study group in these measurements, and Torsional modulus is between $(+3,-3)$ and this gives a direct indication of homogeneity. 
Table (5)

Homogeneity of the research sample in the physical variables under consideration $N=4$

\begin{tabular}{c|c|c|c|c|c}
\hline Variables & $\begin{array}{c}\text { Measuring } \\
\text { Unit }\end{array}$ & SMA & Mediator & $\begin{array}{c}\text { Standard } \\
\text { Deviation }\end{array}$ & $\begin{array}{c}\text { Torsional } \\
\text { modulus }\end{array}$ \\
\hline \hline Pain Level & Degree & 7.200 & 7.000 & 0.837 & 0.512 \\
\hline
\end{tabular}

It is clear from Table (5) that the basic variables under consideration are all homogeneous, which indicates the homogeneity of the study group in these measurements, and Torsional modulus is between $(+3,-3)$ and this gives a direct indication of homogeneity.

Research fields:

The human field:

includes (4) ulnar nerve patients aged (45:30) years.

Time Range:

The basic study (qualification program) was conducted in the period between $5 / 5 / 2018$ to 16/8/2018.

\section{Geographical Area:}

Research experiment was conducted in Mansoura University hospital (Department of Neurosurgery). Tools and means of gathering information:

1- Research measurements and tests:

In the light of many scientific references and previous studies, some measurements and tests for research have been identified:

\section{Anthropometric}

\section{Measurements:}

- The closest age is half a year.

- The closest age weight is kilogram.

- The closest Length is centimeter.

Morphological measurements: (humerus length - forearm length - arm length - flat humerus circumference contracted humerus circumference - forearm circumference - wrist circumference).

\section{Anatomical measurements:}

- Measuring the electrical activity of the muscles working on the elbow and wrist of the hand.

- Measurement of anatomical evaluation of kinetic and sensory conduction of ulnar nerve under consideration.

2- Research instruments and tools:

* Restameter device for 
measuring length $(\mathrm{cm})$.

* Medical scale to measure weight $(\mathrm{kg})$.

* Data registration forms.

* Manometer to measure the strength of the hand grip.

* Goniometer device for measuring the kinetic range of the wrist joint and elbow.

* Measuring tape to measure arm circumference.

* Visual Analogous Scale to measure the degree of pain.

\section{Proposed program:}

The researcher, through the reference research of Arabic and English associated studies, designed a rehabilitation program for muscles which work on the elbow joint and wrist, and which are affected by the injury of the ulnar nerve, to determine the final image of the program in terms of the program duration, the number of stages, time, objectives, the content of each stage and the number of rehabilitation units in each stage. Based on the above, the proposed therapeutic exercise program has been developed as follows: Duration of the program (12) weeks -(3) rehabilitation units per week and the time of the therapeutic rehabilitation unit
(45:60) minutes.

\section{Exploratory Study:}

In the light of the research problem and its hypotheses and the methodology used, the researcher conducted a survey study from 5/5/2018 to $10 / 5 / 2018$, and this study aimed to:

- Checking the validity of measuring instruments.

- Standards of devices used in the research.

- Identifying the suitability of the intensity of the rehabilitation unit for sample members.

- Training to conduct research measurements.

- Determining the order in which measurements are taken.

- Recognizing what the researcher can face from other difficulties.

- Ensuring the validity of the devices and tools used in the tests and their accuracy.

- Identifying the appropriate time and necessary to make measurements for each patient.

- Discovering the difficulties that can face the researcher during the implementation of research procedures and thus find appropriate solutions to it. - Ensuring that the registration process is correct. 


\section{Pre- measurement:}

The researcher conducted the pre-measurements on the members of the research sample in the period from $12 / 5 / 2018$ to $17 / 5 / 2018$. It included anthropometric and anatomical measurements of the ulnar nerve, analysis of the electrical activity of the forearm muscles, hand wrist, morphological measurements, measurement of kinetic range and measurement of pain degree.

\section{Basic Experiment:}

The

program,

therapeutic exercises under research, was applied after conducting ulnar nerve surgery and anatomically modification of its path, and after the rest period of the surgical process. The experiment was applied in the period from 19/5/2018 to $9 / 8 / 2018$ and the program was applied to the members of the research sample for a period of (12) weeks divided into (3) stages, each stage including (4) weeks by (3) rehabilitation units per week during the period of implementation of the rehabilitation program under research.

\section{Post Measurement:}

The Post Measurement was carried out on the sample of the research in the period from $11 / 8 / 2018$ to $16 / 8 / 2018$ in the same order of the premeasurements and under the same conditions.

Statistical treatments used in the research:

The statistical treatments under consideration were used using the spss program and the following treatments were used (arithmetic mean - mean standard deviation - torsion coefficient - indication of differences using Wilcoxon).

\section{Presentation and discussion} of the results:

First: Presentation of the results:

Presentation of the results of the first hypothesis: There are statistically significant differences between the mean of the pre- and postmeasurements of the experimental group in favor of the post-measurements in the improvement of the anatomical evaluation of the kinetic and sensory ulnar nerve in the research sample. 
Table (6)

Significance of differences between pre and post measurements in variables of anatomical evaluation for kinetic and sensory conduction of the ulnar nerve under consideration $N=4$

\begin{tabular}{|c|c|c|c|c|c|c|c|c|c|c|c|}
\hline \multirow{2}{*}{\multicolumn{2}{|c|}{ Variables }} & \multicolumn{4}{|c|}{ Pre- Measurement } & \multicolumn{4}{|c|}{ Post- Measurement } & \multirow[b]{2}{*}{$\begin{array}{c}\text { Value } \\
\text { "z" }\end{array}$} & \multirow{2}{*}{$\begin{array}{c}\text { Improve } \\
\text { ment } \\
\text { Rate }\end{array}$} \\
\hline & & Average & $\begin{array}{c}\text { Deviati } \\
\text { on }\end{array}$ & $\begin{array}{c}\text { Ranks } \\
\text { Average }\end{array}$ & $\begin{array}{c}\text { Total of } \\
\text { Ranks }\end{array}$ & Average & Deviation & $\begin{array}{c}\text { Ranks } \\
\text { Averag } \\
\text { e }\end{array}$ & $\begin{array}{c}\text { Total of } \\
\text { Ranks }\end{array}$ & & \\
\hline \multirow{4}{*}{$\begin{array}{c}\text { the } \\
\text { anato } \\
\text { mical } \\
\text { evalu } \\
\text { ation } \\
\text { of the } \\
\text { kineti } \\
\text { c } \\
\text { condu } \\
\text { ction } \\
\text { of the } \\
\text { ulnar } \\
\text { nerve }\end{array}$} & $\begin{array}{c}\text { Time } \\
\text { taken } \\
\text { for } \\
\text { neuronal } \\
\text { conducti } \\
\text { on }\end{array}$ & 5.06 & 0.20 & 3.00 & 15.00 & 3.02 & 0.45 & 0.00 & 0.00 & 2.023 & $\% 40.31$ \\
\hline & $\begin{array}{c}\text { Nerve } \\
\text { conducti } \\
\text { on force }\end{array}$ & 8.48 & 0.16 & 3.00 & 15.00 & 4.54 & 0.66 & 0.00 & 0.00 & 2.032 & $46.46 \%$ \\
\hline & $\begin{array}{l}\text { Conduct } \\
\text { ion } \\
\text { speed }\end{array}$ & 50.20 & 0.83 & 0.00 & 0.00 & 56.22 & 1.03 & 3.00 & 15.00 & 2.023 & $\% 11.99$ \\
\hline & $\begin{array}{l}\text { Conduct } \\
\text { ion time }\end{array}$ & 34.82 & 0.75 & 3.00 & 15.00 & 30.32 & 0.17 & 0.00 & 0.00 & $\begin{array}{c}- \\
2.023 \\
\end{array}$ & $12.92 \%$ \\
\hline \multirow{3}{*}{$\begin{array}{c}\text { The } \\
\text { anato } \\
\text { mical } \\
\text { evalu } \\
\text { ation } \\
\text { of the } \\
\text { senso } \\
\text { ry } \\
\text { condu } \\
\text { ction } \\
\text { of the } \\
\text { ulnar } \\
\text { nerve }\end{array}$} & $\begin{array}{c}\text { Time } \\
\text { taken } \\
\text { for } \\
\text { neuronal } \\
\text { conducti } \\
\text { on } \\
\end{array}$ & 3.32 & 0.13 & 3.00 & 15.00 & 2.34 & 0.15 & 0.00 & 0.00 & 2.032 & $29.51 \%$ \\
\hline & $\begin{array}{c}\text { Nerve } \\
\text { conducti } \\
\text { on force }\end{array}$ & 11.20 & 0.83 & 0.00 & 0.00 & 16.04 & 0.46 & 3.00 & 15.00 & 2.023 & $\% 43.21$ \\
\hline & $\begin{array}{l}\text { Conduct } \\
\text { ion } \\
\text { speed }\end{array}$ & 3.74 & 0.08 & 3.00 & 15.00 & 2.52 & 0.13 & 0.00 & 0.00 & 2.060 & $32.62 \%$ \\
\hline
\end{tabular}

Crosstab value "Z"at $0.05=1.96$

Table (6) shows that there are statistically significant differences between the pre and post measurements in the neural variables under consideration for the post measurement, the calculated value of $(z)$ is greater than its Crosstab value at the level 0.05 , and the improvement rates ranged between (11.99: $46.46 \%)$.

Presentation of the results of the second hypothesis:

There are statistically significant differences between the mean of pre and post measurements of the experimental group in favor of the post measurements in the improvement of electrical activity of forearm muscles and hand wrist in the research sample. 
Table (7)

Significance of differences between pre and post measurements in variables of analysis of the electrical activity of forearm muscles and hand wrist in the research sample $\mathrm{N}=4$

\begin{tabular}{|c|c|c|c|c|c|c|c|c|c|c|c|}
\hline \multirow{2}{*}{\multicolumn{2}{|c|}{ Variables }} & \multicolumn{4}{|c|}{ Pre measurement } & \multicolumn{4}{|c|}{ Post measurement } & \multirow{3}{*}{$\begin{array}{c}\begin{array}{c}\mathbf{Z} \\
\text { Value }\end{array} \\
-2.041\end{array}$} & \multirow{3}{*}{$\begin{array}{c}\begin{array}{c}\text { Improv } \\
\text { ement } \\
\text { Rate }\end{array} \\
\% 41.32\end{array}$} \\
\hline & & \multirow{2}{*}{\begin{tabular}{|c|} 
Average \\
2.42 \\
\end{tabular}} & \multirow{2}{*}{\begin{tabular}{|c|} 
Aviation \\
0.08 \\
\end{tabular}} & \multirow{2}{*}{\begin{tabular}{|c|}
$\begin{array}{c}\text { Ranks } \\
\text { Average }\end{array}$ \\
3.00 \\
\end{tabular}} & \multirow{2}{*}{$\begin{array}{l}\begin{array}{c}\text { Ranks } \\
\text { Total }\end{array} \\
15.00\end{array}$} & \multirow{2}{*}{\begin{tabular}{|c|} 
Average \\
1.42
\end{tabular}} & \multirow{2}{*}{\begin{tabular}{|c|} 
Aviation \\
0.13
\end{tabular}} & \multirow{2}{*}{\begin{tabular}{|c|}
$\begin{array}{c}\text { Ranks } \\
\text { Average }\end{array}$ \\
0.00
\end{tabular}} & \multirow{2}{*}{$\begin{array}{c}\begin{array}{c}\text { Ranks } \\
\text { Total }\end{array} \\
0.00 \\
\end{array}$} & & \\
\hline $\begin{array}{l}\text { Flexor } \\
\text { carpi } \\
\text { ulnaris }\end{array}$ & $\begin{array}{l}\text { Systolic } \\
\text { force of } \\
\text { the muscle }\end{array}$ & & & & & & & & & & \\
\hline & $\begin{array}{l}\begin{array}{l}\text { Systole } \\
\text { duration }\end{array} \\
\end{array}$ & 25.16 & 0.38 & 3.00 & 15.00 & 16.22 & 0.87 & 0.00 & 0.00 & -2.023 & $\% 35.53$ \\
\hline & & 7.60 & 0.54 & 3.00 & 15.00 & 5.40 & 1.14 & 0.00 & 0.00 & -2.060 & $\% 28.94$ \\
\hline $\begin{array}{c}\text { Musculu } \\
\text { s flexor } \\
\text { digitoru }\end{array}$ & $\begin{array}{l}\text { Systolic } \\
\text { force of } \\
\text { the muscle }\end{array}$ & 4.36 & 0.18 & 3.00 & 15.00 & 2.69 & 0.29 & 0.00 & 0.00 & -2.023 & $\% 38.25$ \\
\hline $\begin{array}{c}\mathrm{m} \\
\text { profund } \\
\text { us }\end{array}$ & $\begin{array}{l}\text { Systole } \\
\text { duration } \\
\end{array}$ & 30.32 & 0.13 & 3.00 & 15.00 & 25.06 & 1.15 & 0.00 & 0.00 & -2.032 & $\% 17.34$ \\
\hline & $\begin{array}{l}\begin{array}{l}\text { Number of } \\
\text { systole stages }\end{array} \\
\end{array}$ & 11.40 & 0.54 & 3.00 & 15.00 & 7.20 & 0.83 & 0.00 & 0.00 & -2.060 & $\% 36.84$ \\
\hline $\begin{array}{l}\text { Muscul } \\
\text { us } \\
\text { abduct }\end{array}$ & $\begin{array}{l}\text { Systolic } \\
\text { force of } \\
\text { the muscle }\end{array}$ & 2.32 & 0.08 & 3.00 & 15.00 & 1.28 & 0.25 & 0.00 & 0.00 & -2.032 & $\% 44.82$ \\
\hline $\begin{array}{c}\text { or } \\
\text { digiti }\end{array}$ & $\begin{array}{l}\text { Systole } \\
\text { duration }\end{array}$ & 28.52 & 0.49 & 3.00 & 15.00 & 20.54 & 0.80 & 0.00 & 0.00 & -2.023 & $\% 27.98$ \\
\hline $\begin{array}{l}\text { quinti } \\
\text { manus }\end{array}$ & $\begin{array}{l}\begin{array}{l}\text { Number of } \\
\text { systole stages }\end{array} \\
\end{array}$ & 11.40 & 0.54 & 3.00 & 15.00 & 6.80 & 0.83 & 0.00 & 0.00 & -2.121 & $\% 40.35$ \\
\hline $\begin{array}{l}\text { Muscul } \\
\text { us }\end{array}$ & $\begin{array}{l}\text { Systolic } \\
\text { force of } \\
\text { the muscle } \\
\end{array}$ & 1.88 & 0.08 & 3.00 & 15.00 & 1.16 & 0.08 & 0.00 & 0.00 & -2.041 & $\% 38.29$ \\
\hline $\begin{array}{l}\text { interos } \\
\text { seus }\end{array}$ & $\begin{array}{l}\begin{array}{l}\text { Systole } \\
\text { duration }\end{array} \\
\end{array}$ & 27.36 & 0.61 & 3.00 & 15.00 & 20.56 & 1.33 & 0.00 & 0.00 & -2.023 & $\% 24.85$ \\
\hline $\begin{array}{c}\text { dorsali } \\
\mathrm{s}\end{array}$ & $\begin{array}{l}\text { Number } \\
\text { of systole } \\
\text { stages }\end{array}$ & 8.20 & 0.83 & 3.00 & 15.00 & 4.80 & 0.83 & 0.00 & 0.00 & -2.121 & $\% 41.46$ \\
\hline $\begin{array}{c}\text { Musculu } \\
\text { s flexor }\end{array}$ & $\begin{array}{l}\text { Systolic } \\
\text { force of } \\
\text { the muscle }\end{array}$ & 2.54 & 0.13 & 3.00 & 15.00 & 1.40 & 0.15 & 0.00 & 0.00 & -2.023 & $\% 44.72$ \\
\hline $\begin{array}{c}\text { digitoru } \\
\mathrm{m} \\
\text { profund }\end{array}$ & $\begin{array}{l}\begin{array}{l}\text { Systole } \\
\text { duration }\end{array} \\
\end{array}$ & 22.72 & 0.13 & 3.00 & 15.00 & 17.84 & 1.18 & 0.00 & 0.00 & -2.023 & $\% 21.47$ \\
\hline $\begin{array}{l}\text { proruna } \\
\text { us } \\
\text { (Forth) }\end{array}$ & $\begin{array}{l}\text { Number } \\
\text { of systole } \\
\text { stages }\end{array}$ & 10.20 & 0.83 & 3.00 & 15.00 & 5.40 & 1.14 & 0.00 & 0.00 & -2.032 & $\% 47.05$ \\
\hline
\end{tabular}

Crosstab value "Z"at $0.05=1.96$

Table (7) shows that there are statistically significant differences between the pre and post measurements in the neural variables under consideration for the post 
measurement, the calculated value of $(z)$ is greater than its Crosstab value at the level 0.05 , and the improvement rates ranged between (17.34: 44.82\%)

Presentation of the results of the third hypothesis:

There are statistically

\section{Table (8)}

Significance of differences between pre and post measurements in Physical variables in the research sample $\quad \mathrm{N}=4$

\begin{tabular}{|c|c|c|c|c|c|c|c|c|c|c|c|c|}
\hline \multirow{2}{*}{\multicolumn{2}{|c|}{ Variables }} & \multirow{2}{*}{$\begin{array}{c}\text { Measur } \\
\text { ing Unit }\end{array}$} & \multicolumn{4}{|c|}{ Pre measurements } & \multicolumn{4}{|c|}{ Post measurements } & \multirow{2}{*}{$\begin{array}{c}\text { Value" } \\
\text { z" }\end{array}$} & \multirow{2}{*}{$\begin{array}{c}\text { Improve } \\
\text { ment } \\
\text { Rate }\end{array}$} \\
\hline & & & Average & Aviation & $\begin{array}{c}\text { Ranks } \\
\text { Average }\end{array}$ & $\begin{array}{c}\text { Ranks } \\
\text { Total }\end{array}$ & Average & Aviation & $\begin{array}{c}\text { Ranks } \\
\text { Average }\end{array}$ & $\begin{array}{c}\text { Ranks } \\
\text { Total }\end{array}$ & & \\
\hline \multicolumn{2}{|c|}{ Grip Strength } & KG & 15.40 & 1.14 & 0.00 & 0.00 & 19.40 & 1.14 & 3.00 & 15.00 & -2.060 & $\% 25.97$ \\
\hline \multirow{4}{*}{$\begin{array}{l}\text { Kin } \\
\text { etic } \\
\text { ran } \\
\text { ge } \\
\text { of } \\
\text { han } \\
\text { d } \\
\text { wri } \\
\text { st }\end{array}$} & Systole & Degree & 122.62 & 0.39 & 3.00 & 15.00 & 112.56 & 1.42 & 0.00 & 0.00 & -2.023 & $\% 8.20$ \\
\hline & $\begin{array}{c}\text { extensio } \\
\mathrm{n}\end{array}$ & Degree & 77.24 & 0.29 & 0.00 & 0.00 & 80.44 & 0.62 & 3.00 & 15.00 & -2.023 & $\% 4.14$ \\
\hline & $\begin{array}{c}\text { allureme } \\
\text { nt }\end{array}$ & Degree & 37.34 & 0.43 & 0.00 & 0.00 & 41.50 & 0.52 & 3.00 & 15.00 & -2.032 & $\% 11.14$ \\
\hline & $\begin{array}{c}\text { retractio } \\
n\end{array}$ & Degree & 23.84 & 0.16 & 0.00 & 0.00 & 27.54 & 0.54 & 3.00 & 15.00 & -2.023 & $\% 15.48$ \\
\hline
\end{tabular}

Crosstab value "Z"at $0.05=1.96$

Table (8) shows that there are statistically significant differences between the pre and post measurements in the physical variables under consideration for the post measurement, the calculated value of $(z)$ is greater than its Crosstab value at the level 0.05, and the improvement rates ranged between (4.14: $25.98 \%$ ). significant differences between the mean of pre and post measurements of the experimental group in favor of the post measurements in the improvement of grip strength and kinetic range of the wrist joint in the research sample. 
Table (9)

Significance of differences between pre and post measurements in level of pain in the research sample $N=4$

\begin{tabular}{|c|c|c|c|c|c|c|c|c|c|c|c|}
\hline \multirow[b]{2}{*}{ Variables } & \multirow[b]{2}{*}{$\begin{array}{l}\text { Measuring } \\
\text { Unit }\end{array}$} & \multicolumn{4}{|c|}{ Pre Measurement } & \multicolumn{4}{|c|}{ Post Measurement } & \multirow[b]{2}{*}{ Value"z" } & \multirow[b]{2}{*}{$\begin{array}{l}\text { Improvement } \\
\text { Rate }\end{array}$} \\
\hline & & Average & Aviation & \begin{tabular}{|c|} 
Ranks \\
Average
\end{tabular} & $\begin{array}{c}\text { Ranks } \\
\text { Total }\end{array}$ & Average & Aviation & \begin{tabular}{|c|} 
Ranks \\
Average
\end{tabular} & $\begin{array}{c}\text { Ranks } \\
\text { Total }\end{array}$ & & \\
\hline level of pain & $\begin{array}{l}\text { Degree } \\
\end{array}$ & $\overline{77.200}$ & 0.837 & $\overline{3.00}$ & $\overline{c 15.00}$ & 3.400 & 0.548 & 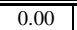 & $\overline{0.00}$ & $-2.070^{\mathrm{b}}$ & \%52.77 \\
\hline
\end{tabular}

Crosstab value "Z"at $0.05=1.96$

Table (9) shows that

there are statistically significant differences between the pre and post measurements in the physical variables under consideration for the post measurement, the calculated value of $(\mathrm{z})$ is greater than its Crosstab value at the level 0.05 , and the improvement rates was $(52.77 \%)$.

Second: Discussion of the results:

In light of the statistical results, objectives and hypotheses of the research, the results are discussed as follows:

Discussion of the results of statistical significance of the first hypothesis:

Table (6) shows that there are statistically significant differences between the pre and post measurements in the neural variables under consideration for the post measurement, the calculated value of $(z)$ is greater than its Crosstab value at the level 0.05 , and the improvement rates ranged between (11.99: $46.46 \%$ ).

These results are also in line with what Hesham Jalal

Mahran (2011) (34) indicates that Therapeutic exercises and therapeutic methods, such as electrical stimulation of the nerves and the affected muscles, help to quickly return the nervous conduction of these nerves and maintain the efficiency of neuromuscular functions.

This is also in line with the conclusions of Nevine Abdellatif Mohamed (1996) 33.

Nathan PA et al. Nathan PA (2001) (46), Ahmed Helmy Ahmed (2009) (1) that there is a change and improvement in nerve conduction due to external program influence with reduction of the symptoms in hand.

Mueller (2006) and oden (2005) emphasize that the effect of rehabilitation exercises increases the ability to regenerate, increase metabolic rate and sensitivity of nerve endings, helping to restore physiological functions of the injury site, making its movements and function in normal directions.

The study of Fatima Hussein Hassan (2004) 17 also 
states that the rehabilitation program of muscles helps in the treatment of joint stiffness, pain relief and restoration of normal kinetic range. This is also in line with what Mohamed Elsayed Elamin refers to, that it is also possible to increase the kinetic range in the joint by using electrical stimulation of the muscles of the joint. The electrical stimulation of the muscles pushes the joint to work within a limited kinetic range. This is consistent with what Ahmed Abd El Azim Gouda refers to, that rehabilitation exercises, electrical stimulation and massage work on the speed of recovery of the nerves to its function and raise its functional efficiency after injury.

The researcher attributes the obvious improvement in the research sample after the application of the rehabilitation program after surgery and the adjustment of the ulnar nerve path. This led to the reduction of pain as well as improving blood flow in the affected arm and improving muscle strength and angular range of the affected joints.

Thus, the first hypothesis, which states that there are statistically significant differences between the median of the pre- and post-measurements of the experimental group in favor of the post-measurements, is achieved in improving the anatomical evaluation of the kinetic and sensory ulnar nerve in the research sample.

Discussion of the statistical significance of the second hypothesis:

Table (7) shows that there are statistically significant differences between the pre and post measurements in the neural variables under consideration for the post measurement, the calculated value of $(\mathrm{z})$ is greater than its Crosstab value at the level 0.05 , and the improvement rates ranged between (17.34: $44.82 \%)$

By reviewing this table, the researcher shows that there is an improvement in the voltage difference of the muscles under investigation.

The increase in the rate of variables of the activity of electrical muscle (E.M.G)) in the post measurements is due to muscle strength and improvement of the level of muscle work due to the positive impact of the rehabilitation program, which the sample was subjected to.

This is in line with the study of Nadia Gharib Hammouda (2002), who stated that when muscle contraction occurs, kinetic units become tired and lose their ability to produce forces. More kinetic units are involved in muscle work and the amount of 
electrical activity changes. When strengthening muscle fibers, electrical activity increases within the muscle depending on its safety, efficiency and work force.

The researcher attributes the remarkable progress in the variable of the strength of muscles working on the elbow joint that the proposed rehabilitation program has a positive effect on the elbow joint as well as the kinetic efficiency of the elbow joint. Muscular contraction is an important mental characteristic because it is linked to the state of both the nervous system and the exercise program that includes static and dynamic muscle strength exercises plays an important and positive role in improving muscle strength.

This is in line with what Islam Ahmed Attia (2012) (6) noted, that the use of rehabilitation exercises and early rehabilitation helps to restore muscle strength quickly to the affected muscles.

This is confirmed by the results of the study of Mustafa Ibrahim Ahmed (2004) (29), Mahmoud Farouk Sabra (2006) (28), Marilyn Fransen Jacques Cruzwin and John Demonds (2001) 44 that the program had a positive impact on the muscle strength of the muscles working on the mentioned joints, and led to a significant return of the muscles to the normal position that were before the injury.

Thus, the second hypothesis, which states that there are statistically significant differences between the averages of the pre- and post-measurements of the experimental group, is achieved in favor of the postmeasurements in improving the electrical activity of the forearm muscles and hand wrist in the research sample.

Discussion of the statistical results of the third hypothesis:

Table (8) shows that there are statistically significant differences between the pre and post measurements in the physical variables under consideration for the post measurement, the calculated value of $(z)$ is greater than its Crosstab value at the level 0.05 , and the improvement rates ranged between (4.14: $25.98 \%$ ).

Ali Mohammed Jalal al-Din (2005) (14) states that the injured limb has less kinetic range due to the presence of the tumor and is affected by the severity of the injury. Positive kinetic range exercises are important in getting rid of the tumor and pain and restore the movement and strength of the joint. Therefore, negative knee joint exercises should be started in all directions but within the limits of pain 
It also confirmed by Abdul Rahman Abdul Hamid Zaher (2004) (13) that fixed exercise improves strength without moving the joints or muscles and this is an important method in the treatment of sports injuries at a time when it is difficult to use other types of exercise.

The researcher attributed the remarkable progress in the variables of the strength of muscle working on the elbow joint resulting from the continuity and regularity in the exercise program rehabilitation, which had a positive impact on the improvement and development of muscle strength of the target muscle group.

This is in line with the results of the study of Mustafa Odeh Amr (2009) (30) and the study of Ahmed Helmi Ibrahim (2009) (1), which confirmed that the rehabilitation program led to the development of improvement in muscle strength and kinetic range.

It also in line with what Farag Abdel Hamid Tawfik (2005) (18) refers to, that the rehabilitation exercises increase the flexibility of the joints and thus increase the kinetic range of of the joint and nutrition of the bones to end properly and works to increase the flexibility of the muscles working on the joint.
This is also confirmed by William A. Miller. \& coctill D (2000) (54) and Jean Dubo (2002) 42 that rehabilitation exercises have a particularly positive role in restoring the kinetic and functional efficiency of the joints and the level of muscle groups to normal in terms of movement and strength.

\section{Mufti}

Ibrahim

Hammad (2004) (31) points out that failure to use the joints regularly during the normal range will result in loss of flexibility in a short period of time. Thus the full kinetic range exercises should be used, The joints need constant movement in a wide range to maintain their kinetic range appropriately.

This is in line with what Mohamed Abdel Hamid Farrag (2004) (23) refers to, that the rehabilitation exercises increase the flexibility of the joint, increase its kinetic range, increase bone nutrition properly and work to increase the flexibility of muscles working on the joint.

Thus, the third hypothesis, which provides that there are statistically significant differences between the mean of the pre and post measurements of the experimental group in favor of the post measurements in the improvement of grip strength and kinetic range of the joints 
which affected by injury in the research sample.

Discussion of the statistical significance of the fourth hypothesis:

It is clear from Table (9)

that there are statistically significant differences between the pre and post measurements in the level of pain under consideration in favor of the post measurement, where the value of the calculated (z) value is greater than the tabular value at a level 0.05 , and the improvement rates was $(52.77 \%)$.

This is in line with what the American Pain Foundation (2006) [55] refers to, that rehabilitation exercises are a common method of rehabilitation and pain management programs. it not only maintain your health, but also help alleviate pain over time. Physical activities help in controlling joint' pain and Swelling due to arthritis.

These views are also consistent with what Fatima Hussein Hassan (2004) refers to, that therapeutic means help in treating joint stiffness, relieve pain and restore normal kinetic range.

These results are also consistent with the results of the study by Dalia Hassan Mansour (2001) (12) and the results of a study by Mustafa Odeh Amr (2009) (30), which confirmed that the rehabilitation program besides physical therapies such as ultrasound has an effective effect in improving the level of pain.

This is in line with what Mohamed Abdel Hamid Farrag (2005) (18) refers to, that the rehabilitation exercises increase the flexibility of the joint, increase its kinetic range, increase bone nutrition properly and work to increase the flexibility of muscles working on the joint.

The researcher attributed this improvement to the fact that he pursued through rehabilitation exercises, whether to develop muscle strength or to increase the flexibility of joints and muscle elasticity and reduce the pressure on the muscles working on the elbow joint, so the pain degree reduces.. The researcher depends on the results of the premeasurements of each patient to determine the physical and anatomical variables of the research sample and how to deal with them individually based on the findings of the previous data for each patient.

The researcher also believes that the use of exercises help to strengthen the muscles working on the elbow joint and lengthen the muscles within the limits of the kinetic range without pain and to commensurate with each stage of rehabilitation, following methods that suit 
each stage.

This is consistent with what Pinarl et pinarl L et.al (2005) 49 concluded, and Caroline Kaisner and Lien Allen (2007) 39 that constituted and mobile rehabilitation exercises help to quickly improve pain relief with improvement in pain. Especially in power of grip.

The researcher has taken into account the diversity in the forms and methods of development of muscle strength of the muscles working on the joint and grip strength, which controls and move the elbow joint and not limited to one type and one method of rehabilitation exercises, which led to the development of muscle strength appropriately, which is one of the most important objectives sought by the rehabilitation program as well as the proper upward gradient that fits with the nature of the injury where the field was available to practice rehabilitation exercises during the program period on the muscles working on the elbow joint and wrist joint, which helped to develop the targeted muscle groups.

This is confirmed by Abdul Rahman Abdul Hamid Zaher (2004) (13) that rehabilitation exercises improve strength without any movement of the joint or muscles and this is an important method in the treatment of post-traumatic injuries during or during sports. The researcher 's interpretation of the results confirms what was pointed out in this regard by Osama Mustafa Riad, Nahed Ahmed Abdul Rahim (2001) that Regular rehabilitation programs should be performed regularly in order to achieve the goal of rehabilitating different body systems.

Thus, the fourth hypothesis, which provides that there are statistically significant differences between the mean of the pre and post measurements of the experimental group in favor of the post measurements in improving the degree of pain associated with injury in the research sample.

\section{Conclusions:}

Based on the findings of the researcher within the limits of the nature of the results of the research, the goal and method used and the sample of research, within the means of data collection, methods of statistical analysis used, the following conclusions were reached:

- The rehabilitation program has a positive impact on the injured under consideration.

- Increasing the kinetic range of the arm and wrist joint in all directions.

- Pain relief of pressure on the 
ulnar nerve.

- The balanced development of muscle strength, joint flexibility and elongation of muscles have an important effect in increasing the kinetic efficiency of the arm and also the wrist joint.

- An improvement in the degree of conduction of the ulnar nerve.

- The diversity in the use of flexibility exercises, stretching and muscle strength exercises had a positive impact on the improvement of the functional performance of the wrist joint.

- The use of a variety of exercises in the rehabilitation program has an effective effect in improving the condition of the injured.

- An improvement in the grip strength of the injured hand.

- The use of various methods and methods between fixed and mobile muscle work in the implementation of stretching exercises and muscle strength has been effective in lengthening the target muscles in the research.

- The exercises of rehabilitation program showed an improvement in the dimensional measurements of all research variables (strength of general muscle on the wrist joint - Kinetic range of the wrist joint - alleviation of pain resulting on the wrist joint)

Research Recommendations:

In the light of the conclusions reached, the researcher recommends the following:

- The importance of magnetic resonance imaging for such cases of because of their significant impact in the diagnosis of this injury, with emphasis on the anatomical characteristics of the elbow joint.

- Do not rush to use the topical injection of Cortisone or surgical intervention only in cases that not respond to rehabilitative exercise programs.

- Guided by the rehabilitation program and the generalization of its use in centers, treatment institutions and hospitals.

- Attention to this awareness of programs and the preparation of rehabilitation programs for other types of diseases and injuries.

- Attention to early detection of cases of ulnar nerve inflammation of the elbow joint even that the infection does not reach the acute and chronic degrees advanced.

- The need to take into account the diversity between fixed and mobile muscle work during the implementation of stretching exercises or muscle strength commensurate with the situation of each injured and 
the direction of injury and rehabilitation stages in such injuries.

- Spreading the cultural awareness among the members of the community towards attention to detect ulnar nerve injury to prevent the worsening of the injury to advanced degrees.

- Continue to perform muscle strength and flexibility exercises even after the completion of the rehabilitation program.

- Designing a kinetic exercise program to prevent exposure to ulnar nerve injury for different categories of society according to the nature of their work and their age.

- Linking the sciences of physical education and the service of the human community in many different fields.

- Directing researchers to carry out similar studies on different stages of men and women as well.

Arabic and English references:

First: Arabic References:

1- Ahmed Helmy Ibrahim:

Rehabilitation Exercise

Program and Its Effect on Carpal Tunnel Syndrome Without Surgery, Master Thesis, Faculty of Physical Education, Tanta University, 2009.
2- Ahmed Suleiman Ibrahim:

Physiology, Unpublished

Notes, Faculty of Physical

Education,

University, 2015.

3- Ahmed Salah Karaa: A Proposed Rehabilitation Program for Restoring the Efficiency of Some Burns Joints, Research Paper, Assiut Journal for Sports Science and Arts, Issue 14, Faculty of Physical Education, Assiut University, 2003.

4- Ahmed Abdel Azim Thabet: The Effect of a Proposed Program for Some Severe Neuritis Cases, Master Thesis, Faculty of Physical Education, Assiut University, 2012.

5- Osama Mustafa Riad, Nahed Ahmed Abdel Rahim:

Measurement and Kinetic Rehabilitation of the People of Determination, Dar al-Fikr alArabi, Cairo, 2001.

6- Islam Ahmed Mostafa: The Effect of Early Physical Rehabilitation on Improving the Functional Efficiency of the Shoulder Joint after Laparoscopic Intervention for Athletes, Master Thesis, Faculty of Physical Education, Benin, Alexandria University, 2012.

\section{7- Ikbal Rasmi Muhammad:}

Sports Injuries and Methods of Treatment, First Edition, Dar Al Fagr for Publishing and Distribution, Cairo, 2008 
8- Ikbal Rasmi Muhammad, Mohammed Mohammed Swedan: Sports Anatomy, first edition, Dar Al-Fajr for publication and distribution, Cairo, 2006.

9- Ehab Ahmed Mansour: Rehabilitation program for the muscles working on the arm after the hand nerve medial hand 2005.

10- Thabet Rabie Thabet: The effect of a rehabilitation program using exercise and ultrasound on some athletes with lateral condylitis at the elbow joint, Master Thesis, Unpublished, Faculty of Physical Education, Assiut University, 2012.

\section{1- Hassan Mohammed}

Nawasra: Anatomy of the motor system, the collectors House for printing, Alexandria, 2012.

\section{2- Dalia Hassan Mansour:}

The Effect of Two Proposed Methods for the Rehabilitation of the Joint with Bronchitis (Tennis Elbow) Using Electrostimulation.

\section{3- Abdel Rahman Abdel} Hamid Zaher: Encyclopedia of Sports Injuries and First Aid, Book Center for Publishing, Cairo, 2004.

\section{4- Ali Mohammed}

Jalaluddin: sports injury (prevention and treatment), second edition, 2005.

$$
\text { 1. Ali Mohammed }
$$

Jalaluddin: addition in sports injuries, the third edition, 2007
15- Owais Ali Al-Jabali:

Theoretical and Applied Mathematical Training, Jones Publishing House, Cairo, 2000

16- Fatima Hussein Hassan: Electrical stimulation of the percutaneous nerve in the treatment of untreated shoulder stiffness, Master Thesis, Faculty of Medicine, Assiut University, 2004.

17- Farraj Abdel Hamid Tawfik: The Importance of Physical Exercises in Treating Deformities, Dar Al Wafa Our Printing and Publishing, 2005.

18- Farid Mahmoud Othman: Sports Injuries and First Aid for Athletes and All, Dar Al Fikr Al Arabi, Cairo. $2000 \mathrm{~m}$

19- Laila El Sayed Farhat: Measurement and Testing in Physical Education, Book Center for Publishing, Cairo. 2001

20- Magdi Mahmoud and Cook: A Proposed Program for Rehabilitation of Working Muscles on the Shoulder Joint after Repeated Dislocation Repair, Unpublished $\mathrm{PhD}$ Thesis, Faculty of Physical Education, Tanta University, 1996.

21- Mohamed El-Sayed ElAmin and Ahmed El-Sayed Ali: Aspects in Sports Health, Al-Manar Printing House, Cairo, 2005

\section{2- Mohamed Abdel Hamid}

Farrag: Chemistry of Muscle Injury and Physical Effort of Athletes, Dar El Wafaa for Printing and Publishing, Cairo, 2004. 


\section{3- Mohamed Abdel Aziz Mohamed: Therapeutic exercises on some physical and physiological variables associated with arthritis of the wrist joint, unpublished Master Thesis, Faculty of Physical Education, Helwan University, 2002.}

24- Mohamed Fathy Hendy: Sports Medical Anatomy, Dar Al Fikr Al Arabi, 1991.

25- Mohamed Kadry Bakry, Siham El-Ghamry: Sports rehabilitation, sports injuries and first aid, Al-Manar Printing House, 2005

26- Mohamed Moustafa Fadl: Study of Parameters and Functional Variables Associated with Cerebral Palsy Patients as a Basis of Rehabilitation Program, Master Thesis, Unpublished, Faculty of Physical Education, Tanta University, 2007.

27- Mahmoud Farouk Sabra:

The impact of a rehabilitation program on some cases of lumbar disc herniation, Ph.D. dissertation, Faculty of Physical Education, Assiut University, 2006.

28- Mustafa Ibrahim Ahmed: The effect of a proposed rehabilitation program on the functional efficiency of some joints of patients with Rheumatoid arthritis, unpublished doctoral dissertation Faculty of Physical Education, Assiut University, 2004.
29- Mustafa Odeh Amr: The Effect of Rehabilitation Exercises on Laser Functionality of Elbow Joint, Master Thesis, Helwan University, 2009

30- Mufti Ibrahim Hammad:

Fitness through Health and Championship, First Edition, Cairo, 2004.

31-Nadia

Gharib

Hammouda: The Effect of a Proposed Program for Developing Static Balance on the Electrical Activity of Some Upper Muscles, Ph.D. Thesis, Faculty of Physical Education for Girls, Helwan University, 1990.

32- Neveen Abdel-Latif Mohamed: The effect of combining compresses and exercises on the speed of delivery of nerve fibers, Master Thesis, Faculty of Physical Therapy, Cairo University, 1996.

33- Hisham Galal Mahran: Effect of Neuromuscular Electrical Stimulation and Pulsed Electromagnetic Field on Sovement Conduction Speed of Moderate Post-Burn Nerve, PhD Thesis, Faculty of Physical Therapy, Cairo University, 2001.

Second: Foreign References: 34- Alvinn j. Determine: Evaluation and treatment of osteochondritis dissects lesions of the knee surg vo121, no2, p106-114,2008. 
35- Brighton sw lubbe je van der merwe ca: the effect of long-tern exercise program on rheumatoid hand of pubmed 2001.

36- Brininger TL rogers jc holm mb baker na li zm goitz rj: efficy of a fabricated customized splint and tendon and nerve for the treatment of carpl tunnel syndrome a randomized controlled pa usa 2007

37- C. Boonhong J piravej K "Study of the effect of therapeutic ultrasound waves in simple and modified carpal tunnel syndrome"2004

38- Carolyn kisner lynn allen coldy: therapeutic exercise foundations and techniques $5^{\text {th }}$ ed. F.A. Davis company Philadelphia, 2007

39- Clarke aw ahmed m, Curtis m, Connell da: lateral elbow tendinopathy correlation of uitrasound with pain and functional disability 20335508 (pub med - as supplied by publisher,2010.

40- Ekim A "Study of the effect of reduced dose of therapeutic laser in rheumatoid patients with carpal tunnel syndrome"2007

41- Jean Dubois: les principles de 1 , entrainment sportif beaux Universidad Bordeaux, France 2002.
42- Kramer, j, r et al: comparison of clinic- and home-based rehabilitation programs after knee arthroplasty London Ontario Canada.2003.

43- Marlenf, jack c, \&johan D: physical therapy is effective for patients with ostiary thirties of the journal of rheumatology. vol,28:156,4, USA. 2001

44- Mueller Es: influence of training and inactivity on muscle stangth and Phys med rehabil 51:449-482, 2006.

45- Nathan "Study of the effect of aerobic exercises in the delivery of the central nerve and symptoms associated with carpal tunnel syndrome"2001

46- Neves et al "Study on the protective and therapeutic effect of physical activity in carpal tunnel syndrome" 2005 .

47- Oden l: reduction of muscular hypertorus by longerm muscle stear scan j relabel med 13:93-99, 2005.

48- Pinar L Enhos A. adan: can we use nerve gliding exercises in women with carpal tunnel syndrome? Gazi unvisited faculty of medicine department of physiology torchy "2005

49- Robert j, Schwartzman: neurologic examination 1st ed, Blackwell pubishing, inc,2006. 
50- Stalkers, B: Increase Serotonin Naturally, Retrieved from, Edition,USA2008.

51- Stergionulas: Effects of low- level laser plyometric exercises is the treatmen of latears epicondylitis pmid 17603862 (pub med - indexed) 25 (3):205-13,2007.
52- su x, wu zq,cao xm: effects of electroacupuncture of differet frequne for treatment of patients with tennis elbow syndrome, zhonggu 30 (1) 435,2010

53- William a. \& coctill D: physiolog 4 of sport and exercise Champaign U.S.A 2000.

54-www.painfoundation.org//-treatment options: A Guide for people living with pain foundation, 2006 . 